\title{
有用化学物質の高収率・高選択率回収を目指した 石炭の新しい迅速熱分解法
}

\author{
(キーワード 石炭の迅速熱分解, 石炭の溶剤膨潤, 溶剂からの水素移行, B T X)
}

京都大学 前 一広 ${ }^{* 1}$, 三浦 孝一 ${ }^{* 1}$, 桜田 清恭*1, 橋本 健治*2

\section{1. 緒 言}

石炭を有効に利用するには，石炭を単にエネルギー 源のみとしてだけでなく，貴重な化学原料源として有 効に利用していく石炭転換技術の開発が重要であると 考えられる。石炭の迅速熱分解は, ベンゼン, トルエ ン, キシレン（BTX）等の有用化学物質を得るプロ セスとして有望視されている。石炭は元来水素含有量 が少ないため, 液収率や BTX 等の収率を増すには, 迅速熱分解時に外部から効率的に水素原子を供与する 必要がある。このような観点から，石炭の熱分解中に 水素ガス ${ }^{1)}$ や有機物質 ${ }^{2) ~ 7)}$ から水素原子を供給する 試みが実施されているが, 液収率を増加させるには 至っておらず，石炭の初期熱分解反応の制御が非常に 困難であることを示している。

水素原子を石炭に効率的に供与し石炭転化率を増加 させるには，まず第一に供与水素原子の生成速度を石 炭からの熱分解ラジカルの生成速度に合致させねばな らない。さらに，両ラジカルが近接して存在していな ければならない。この考えに基づき，我々は初期熱分 解反応を制御し，全揮発分収率と夕ール収率を飛躍的 に増加させる新しい迅速熱分解法（溶剂膨潤熱分解

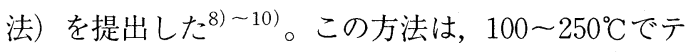
トラリンによって膨潤前処理した石炭を大気圧のへリ ウム雲囲気で迅速に熱分解するものである。石炭をテ トラリンで膨潤すると，テトラリンはその分子サイズ と同程度のミクロ細孔に侵入し保持される。キュー リーポイントパイロライザーを用いて膨潤炭を590 $920^{\circ} \mathrm{C}$ 範囲で迅速に熱分解した結果，石炭転化率は

* 1 工学部附属重質炭素資源転換工学実験施設 * 2 工学部化学工学教室 京都市左京区吉田本町
太平洋膨潤炭で $56 \mathrm{wt} \%$, Morwell 膨潤炭で $67 \mathrm{wt} \%$ に 達した。この飛躍的な増加は膨潤による物理的効果と テトラリンからの効率的水素供与によってもたらされ た。

一方, 石炭の迅速熱分解はベンゼン, トルエン, キ シレン（BTX）等の有用化学物質を得ることに一つ の目的があり, タール中の有用化学物質の選択率を向 上させることもまた重要である。その一つの方法とし て, 我々は各種の溶剂蒸気雲囲気中で石炭を迅速熱分 解する方法 (溶剂同伴熱分解法) を提案した ${ }^{11)}$ 。こ の方法は同伴した溶剂蒸気の分解で生成した水素原子 によって二次的気相反応を制御するもので, 溶郕種を 変えることによって, 水素原子供与量とその速度を幅 広く変化させることができる。たとえば, Morwell 褐 炭を 2 -メチル-1 -プロパノール蒸気中で迅速熱分解 することにより，BTX 収率をこれまでの 5 倍強にあ たる $6.4 \mathrm{wt} \%$ まで増加させることに成功している。

このように, 初期熱分解反応および二次的気相反応 のそれぞれを制御できる熱分解法を提出してきたが, 溶剂膨潤熱分解法の妥当性はキューリーポイントパイ ロライザーで数 $\mathrm{mg}$ の試料を熱分解して検討したのみ であることや，生成タールの分析を十分行っていない など，実用的な面からの検討は不十分であった。

そこで本研究では, まず, 連続式粒子落下型熱分解 装置を用いて, テトラリン膨潤炭の迅速熱分解を実施 し, タールの質的評価も含めて先に提出した溶剤膨潤 熱分解法の実装置での有用性について検討した。さら に, 転化率, BTX 収率・選択率を同時に大幅に増加 させる万法として, 溶剤膨潤熱分解法と溶剂同伴熱分 解法を組み合わせた溶剂膨潤一溶剤同伴熱分解を実施 
し，その有用性について検討した。

\section{2. 実 験}

\section{1.テトラリン膨潤炭の調製}

石炭は豪州褐炭のMorwell 炭（MW）を74 120 $\mathrm{m}$ に微粉砕，ふるい分けしたものを 1 昼夜 $110^{\circ} \mathrm{C} て ゙$ 乾 燥したのち使用した。MW炭の物性をTable 1 に示す。 溶剤は膨潤溶剤としてテトラリンを, 同伴溶剤として テトラリン，2-メチル-1-プロパノール（2M1P） を 使用した。溶剤膨潤炭の調製は以下のように実施した。 石炭粒子とテトラリンを10/6の重量比でステンレス製 の高圧容器に仕込み, 窒素で置換後 $1 \mathrm{MPa}$ まで昇圧

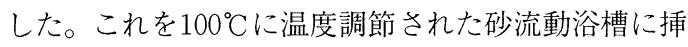
入し 1 時間保持した。この処理によって石炭粒子は膨 潤し，テトラリンは石炭のマトリックス内に保持され る。テトラリンの含浸量は, 膨潤炭の室温下での真空 乾燥の時間を变化させて調整した。本実験では石炭当 たり $22 \%$ になよう調整した。

\section{2 連続式粒子落下型熱分解装置による迅速熱分} 解

Fig. 1 に実験に使用した粒子落下型迅速熱分解装置 の概略図を示す。反応器は外径 $0.0196 \mathrm{~m}$, 内径 $0.0145 \mathrm{~m}$ ，長さ $1.1 \mathrm{~m}$ のステンレス製の直管である。 加熱は, 内径か $0.060 \mathrm{~m}$, 全長 $1 \mathrm{~m}$ （加熱長 $0.8 \mathrm{~m}$ ）を 5 分割した電気炉を用い，それぞれを独立に温度制御 して反応管の長さ方向の温度が均一になるようにした。 石炭及びテトラリン膨潤炭は $11 / \min$ の窒素とともに $0.04 \mathrm{~kg} / \mathrm{h}$ 程度の速度でホッパーからスクリュー フィーダーによって反応管へ供給される。一方，溶剤 蒸気はマイクロポンプによって0.008kg/h の速度で蒸 発器へ送られ，そこで蒸気になって反応器に供給され 石炭粒子と混合される。反応器に供給された石炭粒子 は, 反応器下部へ気流搬送される間に非常に速い昇温 速度で昇温・熱分解される。石炭粒子の反応管内滞留 時間は予備実験から約 2 秒と推定された。固体生成物 のチャーは反応管下部でタール, ガス生成物と分離さ れ，チャー捕集器で完全に捕集される。タールおよび 凝縮性ガス生成物は水水及びドライアイスーメタノー ルの捕集器で完全に捕集される。一方, 非凝縮性ガス
生成物は石けん膜流量計で出口流量を測定後, 一部を ガスバッグで採取して組成分析を行った。タールおよ びチャー収率は各捕集器の重量変化から算出した。石 炭を溶剤蒸気中で熱分解すると溶剂蒸気も同時に熱分 解される。そこで, 溶剂蒸気の熱分解収率への寄与を 調べるため, 溶剤蒸気のみを上述と同様の方法で供給 し熱分解を実施した。さらに比較のため, 石炭の窒素 気流中での迅速熱分解も実施した。全ての実験で物質 収支は98 103\%以内であった。

\section{3 生成物の分析}

ガスバッグで採取した非凝縮性ガス生成物はポラ パック Qカラムを備えたガスクロマトグラフで分析し, 無機ガス $\left(\mathrm{CO}, \mathrm{CO}_{2}, \mathrm{H}_{2} \mathrm{O}, \mathrm{H}_{2}\right)$ および炭化水素ガス $\left(\mathrm{CH}_{4}, \mathrm{C}_{2} \mathrm{H}_{4}, \mathrm{C}_{2} \mathrm{H}_{6}, \mathrm{C}_{3} \mathrm{H}_{6}, \mathrm{C}_{3} \mathrm{H}_{8}, \mathrm{C}_{4} \mathrm{H}_{8}, \mathrm{C}_{4} \mathrm{H}_{10}\right.$, $\mathrm{C}_{5}, \mathrm{C}_{6}$ 化合物）の定量を行った。タール成分は OV-17 もしくはOV-101カラムを備えたGC-MS（島津GCMS QP-1000）抽びガスクロマトグラフ（FID）でその 主成分 (メ夕ノール, 2-メチル-1-プロパノール, ベ ンゼン, トルエン, キシレン, エチルベンゼン, イン デン, テトラリン, ナフタレン, 1-メチルナフタレン, フェナントレン, アルキルフェナントレン）を同定, 定量した。また, 液状生成物中の水収率は, Karl Fischer 水分計（京都電子製MKS- $3 \mathrm{P}$ ）を用いて定量し た。

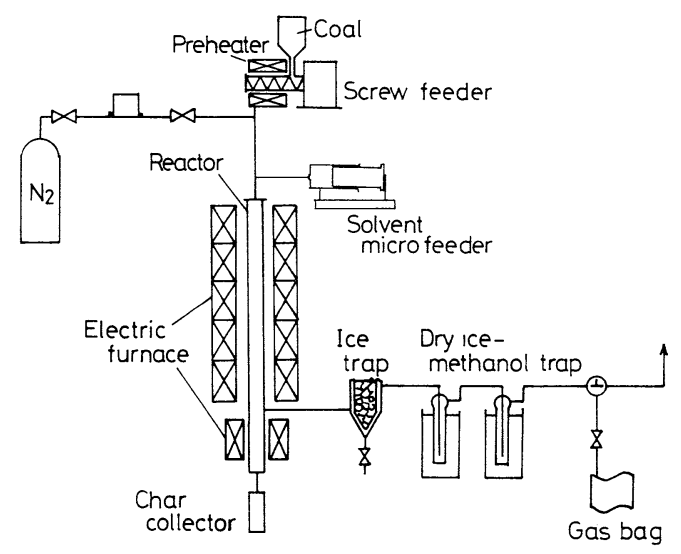

Fig. 1 Schematic diagram of a free-fall pyrolyzer

Table 1 Properties of Morwell coal

\begin{tabular}{lccccccccc}
\hline & \multicolumn{3}{c}{$\begin{array}{c}\text { Proximate analysis } \\
\text { (wt \%) }\end{array}$} & \multicolumn{4}{c}{$\begin{array}{c}\text { Ultimate analysis } \\
\text { (wt \% daf) }\end{array}$} \\
\hline Coal (Abbre.) & FC & VM & Ash & C & H & N & S & O \\
Morwell (MW) & 48.2 & 50.3 & 1.5 & 67.1 & 4.9 & 0.6 & 0.3 & 27.1 \\
\hline
\end{tabular}


タール分析結果から，BTX，テトラリン，ナフタ レン，および沸点範囲（B. P.）が $140-240^{\circ} \mathrm{C}$, 240-300 $\mathrm{C} ， 300^{\circ} \mathrm{C}$ 以上の成分の収率を算出した。

\section{3. 結果と考察}

\section{1 テトラリン膨潤炭の迅速熱分解}

Fig. 2 a,bに，テトラリン膨潤炭を粒子落下型装置 で熱分解したときの各生成物の収率をキューリーポイ ントパイロライザー (CPP) で得られた結果 ${ }^{8)}$ と対比 させて示した。図中の各収率は全て石炭 $100 \mathrm{~kg}$ 基準の 值で，黒塗りのバーは膨潤炭を熱分解した時の収率を 示している。一方，白ぬきのバーは原炭を，網掛けの バーはテトラリン蒸気のみを熱分解した時の収率を示 しており，両者をたし合わせたものと黒塗りのバーを 比較することでテトラリン膨潤の効果を検討できる。

まず，Fig. 2 a，b 中の粒子落下型装置での熱分解 結果から，テトラリン膨潤炭の全揮発分，タール，炭 化水素ガス (HCG)，BTX，CO 収率は，原炭の各収 率に比べ大幅に増加していることがわかる。特に,
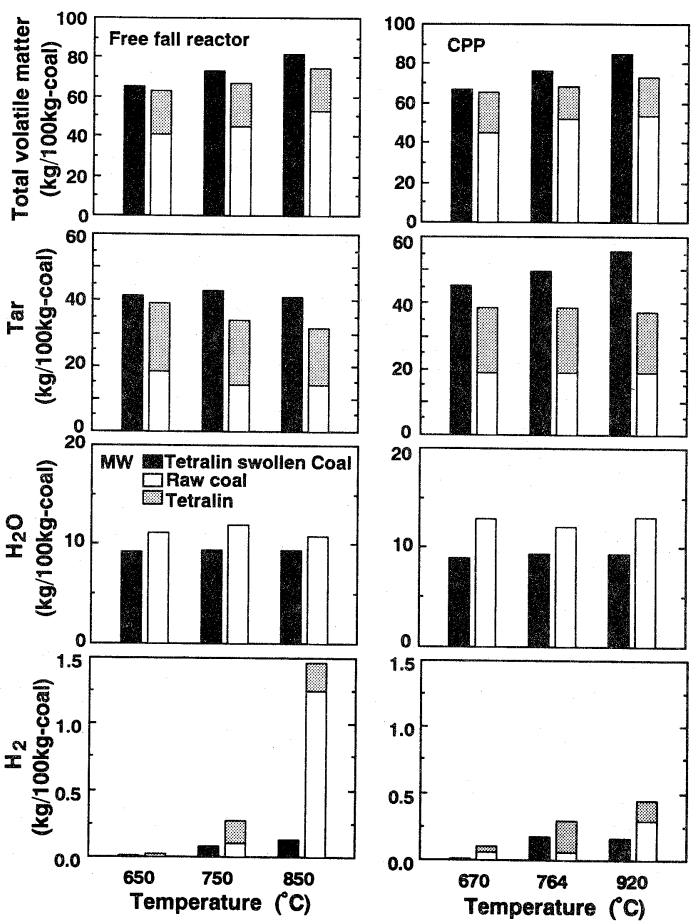

Fig. 2a Comparison of the product distribution (total volatile matter, tar, $\mathrm{H}_{2} \mathrm{O}$ and $\mathrm{H}_{2}$ ) obtained from the flash pyrolysis of the tetralin swolIen Morwell coal

$\left(\begin{array}{l}\text { Left: Pyrolysis in a free-fall pyrolyzer } \\ \text { Right: Pyrolysis in a Curie-point pyrolyzer }\end{array}\right)$
タール収率は $750^{\circ} \mathrm{C} て ゙$ 最大值をとり，原炭とテトラリ ンをそれぞれ熱分解した時のタール収率の和に比べ, $10 \mathrm{~kg} / 100 \mathrm{~kg}$-coal も増加した。一方，テトラリン膨潤 炭の水収率は全温度域で原炭に比べ減少した。これは, テトラリン膨潤によって，石炭内の水素結合が解放さ れ，水生成を伴う架橋形成反応が抑制されていること を示している ${ }^{9)}$ 。この結果，解放された水素結合に関 与していた酸素原子は初期熱分解夕ール中に含酸素化 合物として存在していると考えられる。このことは, タールの二次気相反応が活発になる $750,850{ }^{\circ} \mathrm{C}$ で,

Fig. 2 b に示すように，テトラリン膨潤炭のCO 収率 か増加している点からも明らかである。

次に，粒子落下型装置とCPP で得られた結果を比 較した。まず，原炭の全揮発分収率の増加の程度，水 収率の減少の程度はほぼ同じであった。一方，連続装 置による膨潤炭の夕ール収率は $700^{\circ} \mathrm{C}$ 以上の温度域で 増加し始め $750^{\circ} \mathrm{C} て ゙$ 最大值をとり，その増加量はCPP に比べ小さい。これは，HCG，BTX，CO 収率の顕著
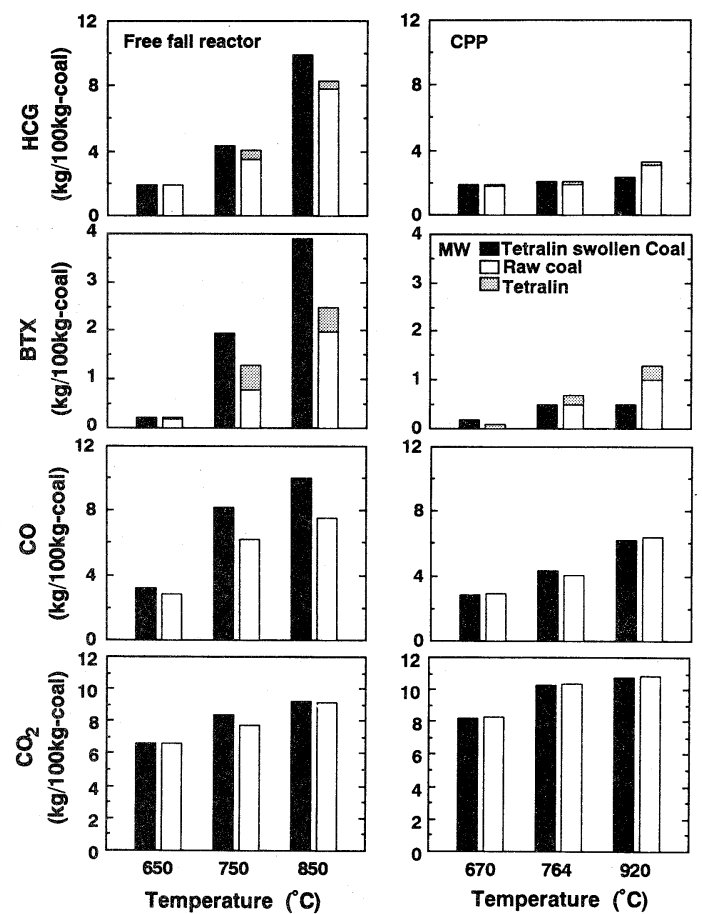

Fig. $2 \mathrm{~b}$ Comparison of the product distribution ( $\mathrm{HCG}, \mathrm{BTX}, \mathrm{CO}$ and $\mathrm{CO}_{2}$ ) obtained from the flash pyrolysis of the tetralin swollen Morwell coal

$\left(\begin{array}{l}\text { Left : Pyrolysis in a free-fall pyrolyzer } \\ \text { Right : Pyrolysis in a Curie-point pyrolyzer }\end{array}\right)$ 
な増加を見てもわかるように，粒子落下型装置では $\mathrm{CPP}$ と異なり, 高温気相中での夕ールの二次的反応 が進行するため, タール収率の増加量が抑えられるこ とを示している。

\section{2 膨潤による熱分解反応機構の変化}

迅速熱分解におけるテトラリン膨潤の効果をより明 らかにするために, テトラリン膨潤炭の窒素気流中で の迅速熱分解と原炭のテトラリン蒸気中での迅速熱分 解結果を比較した。ここで, テトラリン蒸気の供給量 は石炭 $100 \mathrm{~kg}$ 当り $22 \mathrm{~kg}$ で，テトラリン膨潤炭中のテト ラリン量と同じにした。Fig. 3 にHCG 収率, タール を沸点範囲 (b.p.) で 3 分割した収率, チャー収率を 石炭 $100 \mathrm{~kg}$ 当たりで示した。眓の見方はFig. 2 a, b と 同様である。まず，チャー収率を比較すると，テトラ リン膨潤の場合, $750,850^{\circ} \mathrm{C}$ で原炭の場合よりも小さ

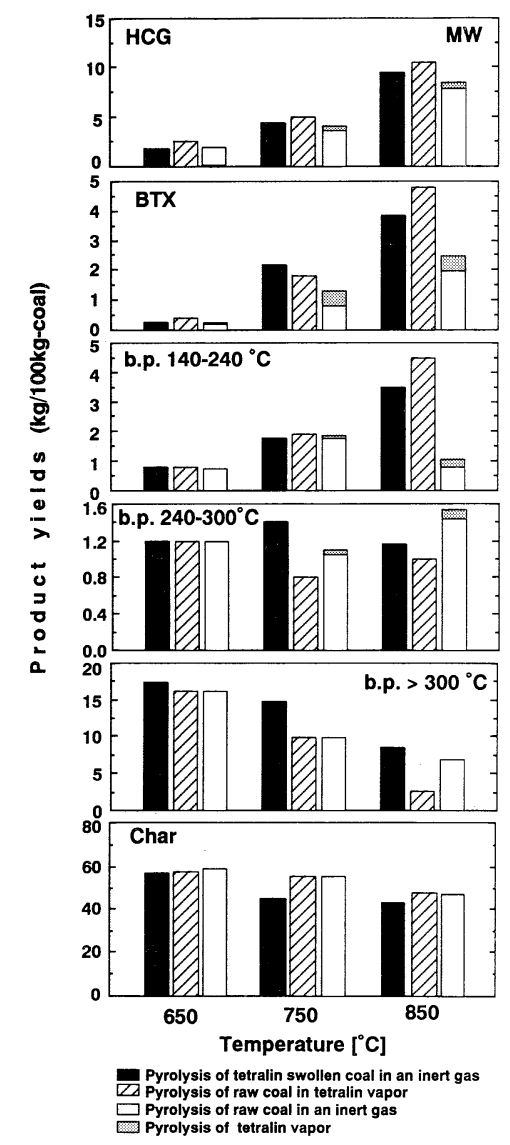

Fig. 3 Comparison of the tar components produced among three pyrolysis methods : pyrolysis of the raw coal in an inert gas, pyrolysis of the raw coal in a tetralin vapor, and pyrolysis of the tetralin swollen coal in an inert gas
くなっているのに対し，テトラリン蒸気同伴では, 原 炭の場合とほほ同じで変化がない。次に, タールの生 成物分布を比較するとテトラリン膨潤炭の熱分解の場 合, $750^{\circ} \mathrm{C}$ では沸点範囲が $300^{\circ} \mathrm{C}$ 以上, $240-300^{\circ} \mathrm{C}$ の成 分が大きく増加している。これが， $850^{\circ} \mathrm{C}$ の高温にな ると, $140-240^{\circ} \mathrm{C}$ ( 2 環化合物), BTX の軽質液状成 分および HCG の増加が顕著になっている。これは, 高温では生成タールの気相での二次反応が進行してい ることによる。一方，テトラリン蒸気同伴の場合, $650,750^{\circ} \mathrm{C}$ では $300^{\circ} \mathrm{C}$ 以上の重質な成分も原炭と変わ らない。しかしながら, $850^{\circ} \mathrm{C}$ の高温になると, 蒸気 同伴によって $240^{\circ} \mathrm{C}$ 以上の成分が大きく減少し, HCG, BTX， $140-240^{\circ} \mathrm{C}$ の成分が増加している。このとき全 タール収率は減少していることから, 蒸気同伴により タールの二次気相反応が促進されたことを示している。 このように，初期熱分解反応に効果をもたらすには, 膨潤していることが不可欠であることが示唆された。

上述の点をさらに明らかにするため供給テトラリン の熱分解時の変化を追跡した。Fig. 4 に両熱分解にお いて, 生成物中に残存するテトラリン量とテトラリン の脱水素生成物であるナフタレン生成量の熱分解温度 による变化を比較した。各量は石炭 $100 \mathrm{~kg}$ あたりで, Fig. 3 と同様に示されている。テトラリン蒸気のみお
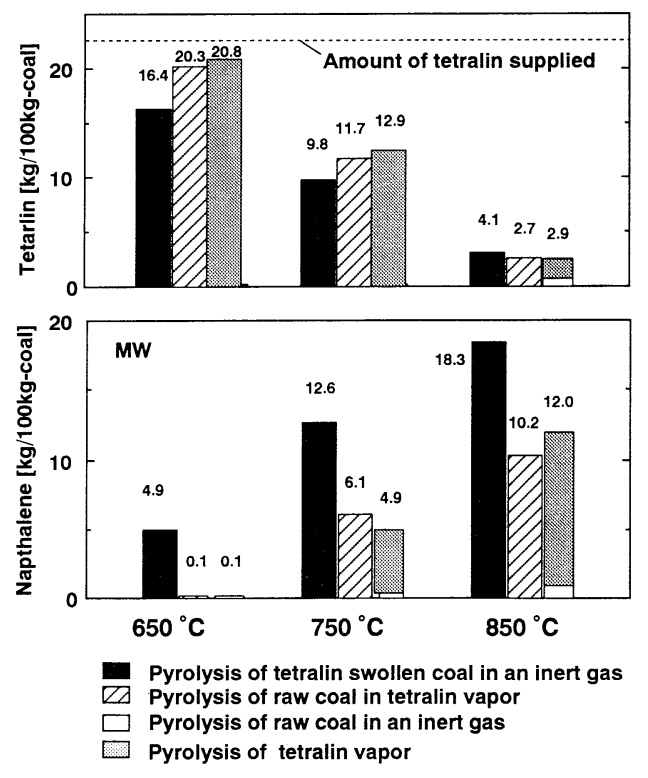

Fig. 4 Comparison of the conversion from tetralin to naphthalene between the pyrolysis of the tetralin swollen coal and that of the raw coal in the tetralin vapor 
よびテトラリン蒸気を同伴した熱分解と比較すると, テトラリン膨潤炭の熱分解では，低温からテトラリン の反応が促進されており，しかもほぼナフタレンへの 脱水素反応のみが進行している。一方，テトラリン蒸

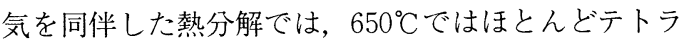
リンは反応していない。750，850 Cでは，供給テトラ リン量よりも未反応テトラリン量と生成したナフタレ ン量の和の方が小さくなっており，かなりの量のテト ラリンがBTX，HCG などへ熱的に分解していること を示している。これらの事実は，テトラリンが，石炭 のミク口細孔内に存在する場合と気相に存在する場合 でテトラリンの反応挙動が異なることを示している。 膨潤炭の熱分解時にはミクロ細孔内に存在するテトラ リンは，ごく近傍に熱分解フラグメントが存在するた めに水素引き抜き反応，すなわち脱水素反応によりナ フタレンへ変化する。その結果，効率的に水素移行が 起こり，転化率，タール収率が大幅に増加したものと 考えられる。生成したナフタレンは熱的に比較的安定 であるため，短い滞留時間ではそれ以上分解されない ものと考えられる。一方，気相のテトラリンは熱的な 分解によってナフタレンの生成と同時に一部 C-C 結 合の解裂が進行し, BTX, HCG を生成していくもの と予想される ${ }^{5)}$ 。

以上，溶剤膨潤炭の迅速熱分解は粒子落下型装置で も転化率，タール収率の大幅な増加に効果があり， $850^{\circ} \mathrm{C}$ の高温ではBTX 等の有用化学物質を約 2 倍程度 まで増加できることがわかった。このように，溶剤膨 潤法は粒子落下型装置においても，石炭の初期熱分解 反応過程を制御し，転化率，タール収率を向上させる
有効な熱分解法であることが示された。

\section{3 溶剤膨潤一溶剂同伴熱分解法への複合化}

以上の結果から，溶剤膨潤熱分解法では，非常に速 い初期熱分解反応を制御して転化率，夕ール収率を増 加できること，一方溶剤同伴熱分解法 ${ }^{11)}$ では，溶剂 種，熱分解温度を適切に選択することで二次的気相反 応を制御して BTX 等の特定の成分を飛躍的に増加で きることが明らかになった。これらの結果から，膨潤 と同伴に用いる溶剤と，熱分解温度を適切に選び，溶 剂膨潤熱分解法と溶剤蒸気同伴熱分解法を組み合せる ことで転化率，タール収率を増加させると同時に BTX を高収率・高選択率で回収できる可能性がある。 そこで，膨潤溶剤としては水素供与能の優れたテト ラリンを, 同伴溶剤としては BTX 収率の増加に効果

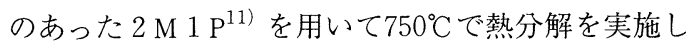
た。Fig. 5 にその結果を示す。図中の各収率は石炭 $100 \mathrm{~kg}$ 基準で示してある。比較として，テトラリン膨 潤炭の窒素気流中での熱分解結果に $2 \mathrm{M} 1 \mathrm{P}$ のみの熱 分解結果を足し合わせたもの，原炭の $2 \mathrm{M} 1 \mathrm{P}$ 中での 熱分解結果にテトラリンのみの熱分解結果を足し合わ せたもの, 原炭の窒素中での熱分解結果にテトラリン, 2 M 1 P それぞれ単独の熱分解結果を足し合わせたも のを示した。熱分解中に石炭, テトラリン， $2 \mathrm{M} 1 \mathrm{P}$ の 3 者に相互作用があるため単純に比較はできないが, 各溶剂からのチャーの生成はないためチャー収率の直 接比較が可能である。溶剤膨潤一溶剤同伴熱分解によ るチャー収率はテトラリン膨潤炭の窒素気流中での結 果と同様大きく減少し，転化率の増加をもたらすこと がわかった。夕ール収率は原炭，溶剤それぞれ単独で

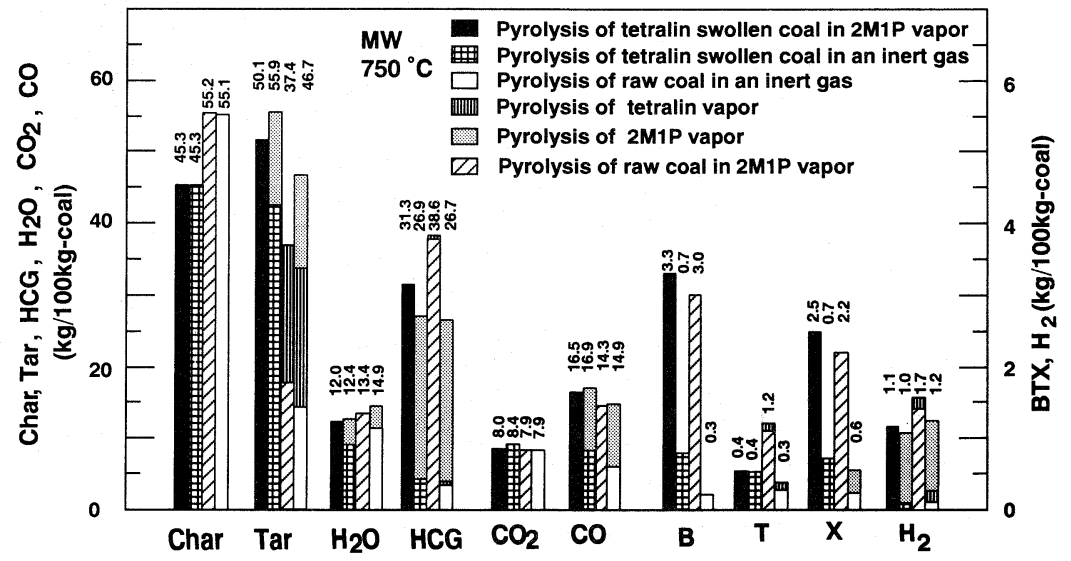

Fig. 5 Product distribution obtained from the flash pyrolysis of the tetralin swollen coal in a 2-methyl-1-propanol vapor 
熱分解した時のタール取率に比べ大きく増加している。 しかし，テトラリン膨潤炭の窒素中での熱分解結果に 2 M 1 P 蒸気単独の熱分解結果を足し合わせた值より は小さい。これは $2 \mathrm{M} 1 \mathrm{P}$ 蒸気の存在でタールの二次 的気相反応が促進されたためと考えられる ベンゼン，キシレン収率はどの組み合わせと比較して も飛躍的に増加しており，BTX 収率は $6.2 \mathrm{~kg} / 100 \mathrm{~kg}$ -coal で，原炭を 2 M 1 P 蒸気中で熱分解して得られ た結果 ${ }^{11)}$ とほとんど同じである。

次に，テトラリンと 2 M 1 P の変化についてFig. 6 に比較した。まず，テトラリン膨潤炭を $2 \mathrm{M} 1 \mathrm{P}$ 蒸気 中で熱分解したときと窒素中で熱分解したときの未反 応テトラリン量及およびナフタレン生成量がほとんど 同じであり，いずれの場合もテトラリンはほぼ量論的 に脱水素されてナフタレンに変化している。また，先 にも述べたようにテトラリン蒸気を単独で熱分解する と脱水素に加えて相当の分解反応が起こる。これらの ことから，膨潤炭中のテトラリンは石炭ミクロ細孔内 で相当量がナフタレンに変化するのみで，二次的気相 反応にはほとんど関与していないと推測される。一方, テトラリン膨潤炭を $2 \mathrm{M} 1 \mathrm{P}$ 蒸気中で熱分解したとき の未反応 $2 \mathrm{M} 1 \mathrm{P}$ 量は, $2 \mathrm{M} 1 \mathrm{P}$ 蒸気を単独で熱分解 した場合より減少しているが，2M 1 P 蒸気中で石炭 を熱分解したときとほぼ同じ值となっている。このこ とより，テトラリン膨潤炭を $2 \mathrm{M} 1 \mathrm{P}$ 蒸気中で熱分解 した場合， $2 \mathrm{M} 1 \mathrm{P}$ 蒸気は生成タールの気相反応にの

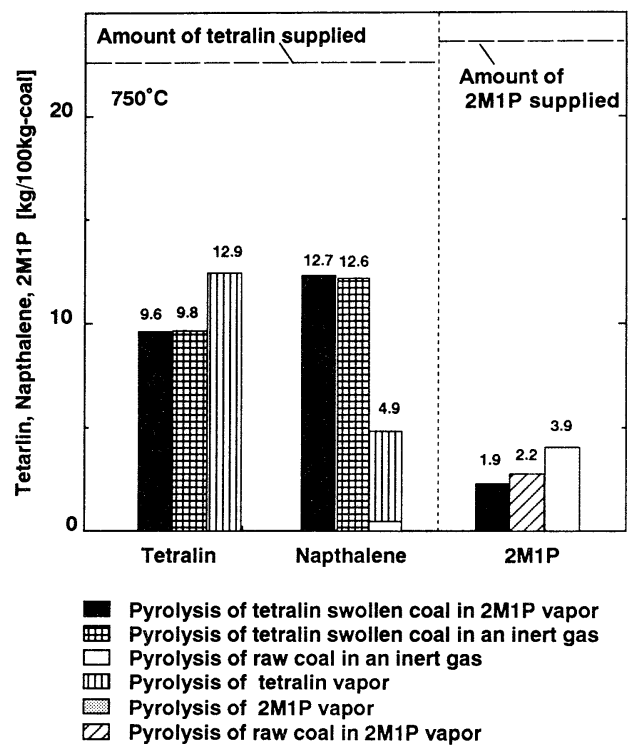

Fig. 6 Comparison of the changes in tetralin and 2M1P among the four pyrolysis methods
み関与しており，テトラリン，ナフタレンにはほとん ど影響を及ぼしていいと考えられた。ここでは，一 例のみを示したが，膨潤溶剂と同伴溶剂の組み合わせ を変えると当然相互作用も変化する。いずれにしても， 溶剂膨潤－同伴熱分解は膨潤溶剤と同伴溶剂を選定す ることにより転化率を増加させると同時に BTX 等の 有用液状成分を高収率・高選択率で回収できることが 明らかになった。

\section{4. 結 論}

石炭の初期熱分解反応を制御して転化率, タール収 率を大幅に増加させる溶剤膨潤熱分解法の実装置にお ける有用性を，テトラリンで膨潤した Morwell 褐炭 を粒子落下型反応器で常圧, 不活性ガス中迅速熱分解 して検討した結果，

1）原炭の熱分解に比べ転化率は $850^{\circ} \mathrm{C} て ゙ 7 \mathrm{~kg} / 100 \mathrm{~kg}$ -coal, タール収率は $750^{\circ} \mathrm{C}$ で $10 \mathrm{~kg} / 100 \mathrm{~kg}$-coal 増加し, 溶剤膨潤熱分解法が実装置においても十分有効である ことが明らかになった。

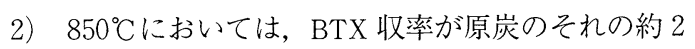
倍に増加することが明らかになり, 本法は有用化学物 質の回収にも効果があることが示された。

3）テトラリンの役割を溶剂同伴熱分解と比較, 検討 した結果，膨潤炭に保持されているテトラリンは，ナ フタレンへの脱水素反応によってタールフラグメント への効率的な水素原子の供与を促進していることが明 らかになった。

次に, 溶剂膨潤熱分解法と溶剤同伴熱分解法の複合 化について検討した結果,

4）本法により石炭粒子内外の 2 つの反応場を同時に 制御することが可能で，転化率の飛躍的な増加と同時 にBTX 等の有用化学物質を高収率・高選択率で回収 できることが示された。

\section{【謝 辞】}

本研究は, 文部省科学研究費補助金『エネルギー重 点領域研究一石炭の総合的利用を目指した複合的変換 プロセスの開発』(課題番号：02203112，03203111） の交付を受けて実施したものである。

\section{文献}

1) Wanzl, W., Fuel Process. Technol., 20, 317 (1988)

2) Calkins, W. H. and Bonifaz, C., Fuel, 63, 1716 (1984)

3) Steinberg, M. and Fallon, P. T., Hydrocarbon Proces., 1982, Nov. p.92

4) Doolan, K. R. and Mackie, J. C., Fuel, 64. 400 (1985) 
5) Run-Ling, R., Itoh, H., Makabe, M., and Ouchi, K., Fuel, 66, 643 (1987)

6) Cypres, R. and Baoqing, L., Fuel Process. Technol., 20, 337 (1988)

7) Hüttinger, K. J. and Sperling, R. E., Proc. Int. Conf. on Coal Sci. 1987, Maastricht, pp. 699

8) Miura, K., Mae, K., Asaoka, S., Yoshimura, T. and Hashimoto, K., Energy \& Fuels, 5, 340
(1991)

9) Miura, K., Mae, K., Yoshimura, T., Masuda, K. and Hashimoto, K., Energy \& Fuels, 5, 803 (1991)

10）三浦孝一, 前 一広, 中川浩行, 内山元志, 橋本 健治，日エネ誌，71，107（1992）

11) Miura, K. Mae, K., Murata, A., Sato, A., Sakurada, K. and Hashimoto, K., Energy \& Fuels, 6, 179 (1992) 


\title{
A Novel and Efficient Coal Pyrolysis Method for Recovering Valuable Chemicals
}

\author{
Kazuhiro MAE ${ }^{* 1}$, Kouchi MiURA ${ }^{* 1}$, Kiyoyasu SAKURADA*1 \\ and Kenji HASHIMOTO ${ }^{2}$
}

\author{
*1 Research Laboratory of Carbonaceous Resources Conversion \\ Technology, Kyoto University \\ *2 Division of Chemical Engineering, Kyoto University
}

SYNOPSIS : - We have recently presented two new pyrolysis methods : one is the flash pyrolysis of coal preswollen with hydrogen donor solvent in an inert atmosphere (method I). This method drastically increased the yields of total volatiles and liquids. The other is the pyrolysis of coal in the atmosphere containing a solvent vapor (method II ). In this method, the BTX yield reached 5 times larger than that in an inert atmosphere.

In this paper an Australian brown coal (Morwell) preswollen by tetralin at $100^{\circ} \mathrm{C}$ was pyrolyzed in a free fall pyrolyzer to examine the validity of the method I in a practical operation. The yields of total volatiles and tar increased at all temperatures. At $850^{\circ} \mathrm{C}$ the BTX yield increased up to $3.9 \%$ which was twice as large as that obtained from the pyrolysis of the raw coal. Apart from the tetralin in the gas phase, the tetralin in the swollen coal was found only to be dehydrogenated to naphthalene during the pyrolysis. This indicates that the incrases in the yields of total volatiles and tar are caused by the effective hydrogen radical transfer from tetralin to coal fragments in the micropores. Thus it is clarified that the method I is also valid in an actual industrial pyrolyzer.

Next, the method I and the method II were combined (method III) to realize effective hydrogen transfer from solvent to coal fragments both in the micropore of the coal and in the gas phase. To examine the validity of the method III, Morwell coal swollen by tetralin was pyrolyzed in a stream of 2-methyl-1-propanol vapor. Both the coal conversion and the liquid yield increased significantly through effective hydrogen transfer within coal particles, and simultaneously the BTX yield increased up to $6.2 \mathrm{~kg} / 100 \mathrm{~kg}$ -coal through the acceleration of the gas phase reaction. Thus it is clarified that the method III is an attractive method to obtain valuable chemicals in high yields and in high selectivities.

\section{Key Words}

Flash pyrolysis of coal, Solvent swelling,

Hydrogen transfer from solvent to coal, BTX 